\title{
Kemampuan Berpikir Kritis Siswa melalui Model STEM PjBL disertai Penilaian Otentik pada Materi Fluida Statis
}

\author{
Nur Diana Rosyidah ${ }^{1}$, Sentot Kusairi ${ }^{1}$, Ahmad Taufiq $^{1}$ \\ ${ }^{1}$ Pendidikan Fisika-Universitas Negeri Malang
}

\section{INFO ARTIKEL}

\section{Riwayat Artikel:}

Diterima: 10-12-2019

Disetujui: $15-10-2020$

Kata kunci:
critical thinking;
static fluid;
authentic assessment;
berpikir kritis;
fluida statis;
penilaian otentik

\section{Alamat Korespondensi:}

Nur Diana Rosyidah

Pendidikan Fisika

Universitas Negeri Malang

Jalan Semarang 5

E-mail: dianarosyidah4@gmail.com

\begin{abstract}
ABSTRAK
Abstract: The purpose of this study is to analyze students' critical thinking especially on static fluid material through STEM PjBL accompanied by authentic assessment. The research design used mixed methods type embedded experimental design and the sample used in the study amounted to 32 students. Through the results of the analysis note that the learning process used is moderately influential on increasing students' critical thinking skills. In general, students experience an increase in all indicators of critical thinking.

Abstrak: Penelitian ini bertujuan untuk menganalisis kemampuan berpikir kritis siswa khususnya dalam materi fluida statis melalui STEM PjBL disertai penilaian otentik. Rancangan penelitian yang digunakan ialah mixed methods tipe embedded experimental design dan sampel yang digunakan dalam penelitian berjumlah 32 siswa. Berdasarkan hasil analisis diketahui bahwa perlakuan yang diterapkan mampu meningkatkan kemampuan berpikir kritis siswa. Secara umum, siswa mengalami peningkatan pada semua indikator berpikir kritis.
\end{abstract}

Berpikir kritis termasuk proses berpikir yang wajib ditanamkan kepada siswa agar siswa mendapatkan pengetahuan yang bermakna. Kemampuan ini mampu membantu siswa untuk menghadapi tantangan revolusi industri di abad 21 (Fayakun \& Joko, 2015; Tiruneh et al, 2017). Berpikir kritis didefinisikan sebagai cara berpikir yang logis serta reflektif yang diterapkan dalam proses pengambilan tindakan (Nuryanti, Zubaedah, Diantoro, 2018). Dalam proses ini siswa harus mempertimbangkan segala kemungkinan yang dapat terjadi sebelum memutuskan suatu hal karena informasi yang diperoleh belum tentu dapat dijadikan sebagai acuan dalam melakukan suatu tindakan. Hasil penelitian terdahulu menyatakan bahwa level berpikir kritis siswa khususnya pada bidang fisika masih tergolong rendah dengan kata lain kemampuan siswa masih di bawah rata-rata (Nuryanti, Zubaedah, Diantoro, 2018; Priyadi, Mustajab, Tatsar, \& Kusairi, 2018; Puspita, Kaniawati, \& Suwarma, 2017). Hal ini ditandai dengan siswa yang hanya mampu menggunakan persamaan matematis tanpa mampu memaknai secara fisis arti persamaan yang telah digunakan, siswa juga tidak mampu memberikan penjelasan terkait alasan atas keputusan yang telah diambil. Salah satu penyebab rendahnya kemampuan berpikir kritis siswa adalah kesalahan siswa dalam memahami suatu konsep. Siswa banyak mengalami kesalahan dalam memaknai konsep-konsep fisika, salah satunya pada konsep fluida statis (Goszewski et al. 2013; Loverude et al. 2010; Wijaya, Koeshandayanto, \& Muhardjito, 2016; Yadaeni, Kusairi, Parno, 2018; Yolanda, Fakhruddin, \& Yennita, 2017). Kondisi ini mendorong adanya perbaikan dalam aktivitas belajar supaya siswa mampu memaknai konsep fisika dengan benar sehingga tingkat berpikir kritis siswa khususnya di bidang fisika juga lebih baik dari sebelumnya.

Project Based Learning (PjBL) merupakan salah satu model yang pada tahapannya melatih serta meningkatkan kemampuan berpikir kritis siswa (Marisda, 2019; Insyasiska, Zubaedah, Susilo, 2015). PjBL membuat siswa berpikir secara inovatif dan kreatif dalam menerapkan strategi yang tepat saat memecahkan suatu masalah (Mihardi, 2013; Mohamadi, 2018). Proses dalam PjBL akan terlaksana secara lebih optimal jika dalam setiap tahapnya di integrasikan dengan STEM. PjBL mengajarkan siswa untuk memahami suatu konsep melalui pembuatan produk, dengan adanya STEM siswa akan berusaha untuk membuat produk terbaiknya melalui proses perancangan dan re-design (Vo, Pang, and Lee 2018). Oleh karena itu, STEM PjBL merupakan perpaduan proses pembelajaran yang dapat digunakan untuk memaksimalkan pelatihan kemampuan berpikir kritis siswa.

STEM PjBL ialah pembelajaran yang dalam prosesnya membimbing siswa untuk menghasilkan proyek. Dalam proses pembuatan proyek diperlukan suatu bahan pengumpul informasi yang berfungsi untuk memantau perkembangan kemampuan siswa. Bahan pengumpul informasi yang dapat digunakan pada proses pembelajaran ini ialah bahan-bahan yang terdapat dalam proses penilaian otentik. Guzzomi dkk. (2017) dalam penelitiannya mengungkapkan bahwa penilaian otentik harus diterapkan pada siswa yang belajar dengan menggunakan unsur engineering supaya siswa lebih termotivasi untuk membuat proyek terbaik. 
Melalui permasalahan yang telah diuraikan, penelitian ini dilaksanakan dengan maksud untuk menganalisis pengaruh STEM PjBL disertai penilaian otentik terhadap kemampuan berpikir kritis siswa khususnya untuk materi fluida statis.

\section{METODE}

Metode yang digunakan dalam penelitian adalah metode campuran (kuantitatif kualitatif) tipe embedded experimental design. Sampel penelitian terdiri dari siswa kelas XI MIPA 6 SMAN 1 Batu (N=32 siswa). Penelitian dilakukan pada bulan Oktober 2019. Instrumen yang digunakan pada proses penelitian ada dua yaitu instrumen perlakukan dan pengukuran. Instrumen yang digunakan pada proses pemberian perlakuan terdiri dari RPP, LKS, lembar observasi dan lembar penilaian otentik. RPP dirancang berdasarkan tahapan pembelajaran STEM PjBL yang telah dirancang oleh Capraro, et al. (2013). Tahapan pembelajaran tersebut terdiri dari (a) identify problem and constraints, (b) research, ideate, (c) analyze ideas, (d) build, (e) test and refine, (f) communicate and reflect. Ketujuh tahapan tersebut kemudian diintegrasikan dengan proses penilaian otentik.

Instrumen yang digunakan sebagai bahan untuk mengukur ialah enam soal berbentuk essay. Setiap soal mewakili indikator berpikir kritis. Indikator yang digunakan pada soal terdiri dari identifikasi hipotesis, kemampuan berpikir deduksi dan induksi, serta kemampuan untuk melakukan penjelasan dan evaluasi. Data yang dianalisis adalah data kuantitatif dan kualitatif. Analisis kuantitatif dilakukan dengan tujuan untuk mengetahui pengaruh STEM PjBL disertai penilaian otentik terhadap kemampuan berpikir kritis siswa. Analisis data kuantitatif terdiri dari perhitungan statistik deskriptif, uji beda, Normalized Gain, dan yang terakhir $d$-effect size. Statistik yang ditampilkan terdiri dari mean, standar deviasi (SD), skewness, nilai minimum dan maksimum. Sebelum melakukan uji beda, terlebih dahulu dilakukan uji normalitas pada data pre-test postest. Apabila nilai skewness pre-test dan postest berada dalam rentang antara -1 sampai 1, maka data terdistribusi normal. Jika hasil perhitungan menunjukkan bahwa data terdistribusi normal, maka uji beda yang digunakan adalah paired sample t-test. Jika sebaliknya, uji beda yang digunakan adalah uji Wilcoxon. Perhitungan N-Gain dilakukan dengan tujuan untuk menganalisis kategori peningkatan ataupun penurunan pada kemampuan literasi sains siswa. N-Gain dianalisis dengan menggunakan kriteria yang telah dirancang oleh (Hake, 1998). Selanjutnya, perhitungan nilai $d$-effect size. Uji ini diproses untuk mengetahui bagaimana pengaruh STEM $\mathrm{PjBL}$ disertai penilaian otentik terhadap kemampuan berpikir siswa. Hasil yang diperoleh dianalisis sesuai dengan kategori yang telah ditetapkan oleh (Cohen, et al, 2017).

Untuk memperkuat hasil analisis dari data kuantitatif, selanjutnya dilakukan analisis pada data yang berbentuk kualitatif. Data kualitatif dihasilkan dari jawaban siswa pada soal dan jawaban saat wawancara. Analisis ini dilakukan untuk mengetahui cara berpikir siswa. Langkah-langkah yang digunakan saat proses analisis adalah pengumpulan data, pengodean data, penyajian data, kemudian dilanjutkan dengan pembuatan kesimpulan.

\section{HASIL}

Kegiatan belajar mengajar dilakukan selama enam kali pertemuan dengan total waktu dua belas jam pelajaran. Pada pertemuan pertama guru mengadakan pre-test untuk menganalisis kemampuan awal siswa. Setelah pre-test guru melakukan wawancara dengan siswa untuk mendalami konsep dasar yang dimiliki siswa. Pada pertemuan kedua pembelajaran diawali dengan tahap identify problem and constraints, ditahap ini guru menyajikan masalah melalui tayangan video dan narasi pada LKPD. Setelah tahap penyajian masalah, guru menerangkan hal apa saja yang harus dilakukan siswa. Kemudian guru menyampaikan tujuan pembelajaran dan membagi siswa kedalam beberapa kelompok. Guru meminta siswa menulis permasalahan dan merumuskan beberapa solusi yang tepat dalam mengatasi masalah tersebut. Tahap ini melatih kemampuan berpikir kritis siswa pada indikator identifikasi hipotesis dan induksi karena dalam tahap ini siswa harus melakukan identifikasi solusi yang tepat dalam mengatasi masalah yang dihadirkan. Pada tahap research, guru meminta siswa untuk mengamati video. Dilanjutkan dengan proses dialog antara guru dengan siswa yang bertujuan untuk mengetahui kemampuan awal siswa dan merangsang siswa untuk mendapatkan solusi tepat dalam mengatasi masalah. Guru meminta siswa untuk mencari solusi melalui berbagai sumber. Selanjutnya, tahap ideate. Pada tahap ini guru meminta siswa untuk mengkaji kelemahan dan kelebihan pada desain yang telah dibuat.

Proses pemilihan desain melatih kemampuan deduksi dan evaluasi siswa.Tahap berikutnya adalah analyze ideas. Pada tahap ini guru mengarahkan siswa untuk menentukan beberapa bahan utama serta kelebihan dan kekurangannya untuk membuat proyek yang sesuai. Pada tahap Build guru memonitoring siswa agar membuat proyek sesuai dengan rancangan yang telah dibuat (melatih kemampuan deduksi dan merancang penyelidikan ilmiah). Pada tahap test and refine guru membimbing siswa melakukan uji proyek. Setelah proses uji proyek, guru membimbing siswa untuk melakukan interpretasi data, tahap ini melatih indicator penjelasan. Kemudian guru mengarahkan siswa untuk redesign jika proyek yang telah dibuat ternyata tidak sesuai tujuan/tidak dapat berfungsi dengan baik. Tahap terakhir adalah communication and reflection. Pada tahap ini guru meminta perwakilan kelompok mengomunikasikan hasil proyek, dimulai dari dari proses perancangan desain sampai dengan pengujian proyek. Siswa lainnya diminta mengomentari hasil presentasi. Diakhir presentasi guru mengajak siswa untuk menarik kesimpulan terkait manfaat dari proses pembuatan proyek. Proyek di nilai sesuai dengan rubrik yang telah dibuat oleh guru. Terdapat delapan aspek yang dinilai, nilai tersebut kemudian disampaikan kepada siswa dengan tujuan untuk memotivasi siswa. Di setiap akhir pertemuan guru selalu memberikan tes formatif kepada siswa untuk mengetahui perkembangan kemampuan siswa. 
Melalui pelaksanaan proses pembelajaran dengan menggunakan STEM PjBL yang disertai penilaian otentik, nilai mean kemampuan berpikir kritis siswa mengalami peningkatan. Peningkatan nilai dari pre-test ke postest melalui perhitungan N-Gain diperoleh sebesar 0,16 (kategori rendah). Berdasarkan hasil analisis diperoleh nilai $d$-effect size sebesar 1,05, artinya model STEM PjBL disertai penilaian otentik yang diterapkan memiliki pengaruh kuat terhadap peningkatan kemampuan berpikir kritis siswa khususnya untuk materi fluida statis.

Data pre-test dan postest dibandingkan untuk mengetahui kemampuan akhir siswa. Berdasarkan hasil perbandingan diketahui bahwa dua puluh siswa mengalami peningkatan skor, sembilan siswa tidak mengalami peningkatan skor dan tiga siswa sisanya mengalami penurunan skor. Statistik deskriptif data pre-test postest untuk kemampuan literasi sains disajikan pada tabel 1.

Tabel 1. Statistik Deskriptif Skor Berpikir Kritis

\begin{tabular}{lcc}
\hline Nilai & Pre-test & Postest \\
\hline N & 32 & 32 \\
Minimum & 6,0 & 6,0 \\
Maksimum & 12 & 14 \\
Median & 8,0 & 9,0 \\
Modus & 8,0 & 9,0 \\
Skewness & 3,2 & 0,8 \\
\hline
\end{tabular}

Berdasarkan tabel 1 yang telah disajikan diketahui bahwa nilai modus dan median skor postest lebih tinggi dibandingkan skor pre-test. Hasil ini mengandung makna bahwa ada peningkatan pada proses berpikir kritis siswa setelah dilakukan kegiatan pembelajaran dengan STEM PjBL disertai penilaian otentik. Selanjutnya, dilakukan analisis statistik inferensial untuk mendukung hasil tersebut. Hasil perhitungan menunjukkan bahwa nilai skewness pada data pre-test sebesar 3,2 dan untuk postest sebesar 0,8. Karena data pre-test tidak terdistribusi dengan normal, maka uji beda yang dipakai ialah wilcoxon. Output dari Wilcoxon Signed Rank Test menunjukkan nilai P-value sebesar 0,00, artinya nilai p lebih kecil dari 0,05. Perolehan ini menandakan jika terdapat perbedaan antara nilai pre-test dan postest siswa.

Kemudian dilanjutkan pada analisis untuk mengidentifikasi seberapa besar peningkatan skor siswa setelah adanya perlakuan. Nilai N-Gain yang didapatkan pada hasil perhitungan sebesar 0,16 artinya peningkatan kemampuan siswa berada dalam kategori rendah. Untuk mengetahui berapa besar pengaruh perlakuan terhadap peningkatan skor siswa, maka proses selanjutnya yang harus dilakukan ialah menghitung nilai $d$-effect size. Nilai $d$-effect size yang diperoleh berdasarkan hasil perhitungan ialah sebesar 0,99 artinya STEM PjBL disertai penilaian otentik memiliki pengaruh sedang terhadap kemampuan berpikir kritis siswa. Analisis selanjutnya adalah melihat progres jawaban siswa dari masing-masing indikator soal. Progres skor tiap indikator soal secara umum ditunjukkan pada tabel 2.

Tabel 2. Progres Jawaban Siswa pada Soal yang diberikan

\begin{tabular}{cclccc}
\hline \multirow{2}{*}{ Nomor Soal } & \multirow{2}{*}{ Tingkat Kognitif } & \multicolumn{1}{c}{ Indikator Berpikir Kritis } & \multicolumn{2}{c}{ Perbandingan Skor Pre-test Postest } \\
\cline { 3 - 5 } & & Meningkat & Tetap & Menurun \\
\hline 1 & C5 & Identifikasi hipotesis dan evaluasi & 7 & 25 & 0 \\
2 & C4 & Induksi dan Penjelasan & 14 & 18 & 0 \\
3 & C4 & Deduksi & 4 & 28 & 0 \\
4 & C4 & Deduksi & 6 & 26 & 0 \\
5 & C4 & Penjelasan dan Identifikasi Hipotesis & 11 & 21 & 0 \\
6 & C3 & Induksi & 4 & 23 & 5 \\
\hline
\end{tabular}

Pada tabel 2 diketahui bahwa mayoritas siswa memiliki nilai pre-test dan postest yang sama. Hasil ini menunjukkan jika tidak semua siswa mengalami peningkatan pada kemampuan berpikir kritis. Hal menarik terjadi pada soal nomor enam. Berdasarkan data yang telah ditampilkan, diidentifikasi bahwa ada lima siswa mengalami penurunan skor pada soal ini. Soal tersebut ditunjukkan pada gambar 1 . 


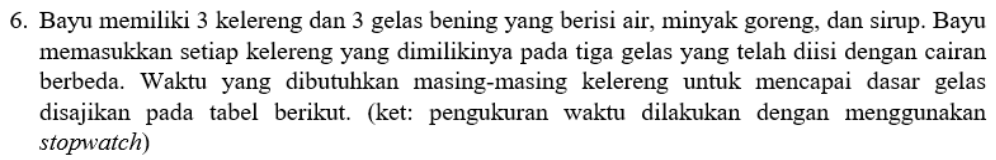

\begin{tabular}{|c|c|}
\hline Jenis Cairan & t (sekon) \\
\hline Air & $00: 00,49$ \\
\hline Minyak goreng & $00: 00,60$ \\
\hline Sirup & $00: 00,54$ \\
\hline
\end{tabular}

Berdasarkan tabel yang telah disajikan, manakah cairan yang memiliki viskositas terbesar dan terkecil?

Jawab:

\title{
Gambar 1. Soal dengan Indikator Induksi
}

Soal pada gambar 1 memiliki indikator menerapkan prinsip viskositas dalam kehidupan sehari-hari. Soal ini digunakan untuk menguji pemahaman siswa pada konsep viskositas serta digunakan untuk menganalisis kemampuan berpikir kritis siswa pada indikator induksi. Pada soal ini siswa diminta untuk mengurutkan cairan yang memiliki viskositas paling besar sampai paling kecil. Berikut contoh jawaban siswa yang mengalami penurunan skor.

\section{Pre-test}

\author{
6. minyak goreng memiliki viskositas terbesar sedangkan air memiliki viskositas terkecil. Alsannya dapat \\ dilihat dari waktu yang dibutuhkan kelereng untuk mencapai dasar gelas. Semakin lama waktu yang \\ dibutuhkan semakin kental.
}

\section{Postest}

\section{6. cairan dengan viskositas terbesar adalah minyak goreng, sedangkan yang memiliki viskositas terkecil adalah air}

\section{Gambar 2. Perbandingan Jawaban Pre-test Postest Siswa}

Berdasarkan gambar 2 diketahui bahwa saat postest siswa tidak menjelaskan alasan terhadap keputusan yang diambil. Hal ini merupakan penyebab utama menurunnya skor siswa. Setelah dilakukan wawancara diperoleh informasi bahwa siswa sudah memahami konsep viskositas, hanya saja dalam menjawab soal siswa tidak menyebutkan alasan dikarenakan pada soal tidak ada perintah untuk melakukan penjelasan terkait jawaban yang diberikan.

\section{PEMBAHASAN}

Secara umum, kemampuan siswa meningkat pada semua indikator, meski peningkatannya tergolong tidak signifikan. Hasil ini memberi arti bahwa STEM PjBL disertai penilaian otentik mampu memperbaiki kemampuan berpikir kritis siswa. Carparo, dkk (2013) menyatakan bahwa adanya engineering pada tahapan STEM PjBL memiliki banyak manfaat terhadap proses pembelajaran. Salah satunya ialah melatih penyusunan struktur yang baik dalam memecahkan masalah yang sifatnya kompleks. Proses latihan penyusunan struktur dalam pemecahan masalah melatih kemampuan berpikir kritis siswa. Identifikasi mengenai penyelesaian terbaik dalam pembuatan desain membutuhkan pemikiran yang cermat pada diri siswa, latihan ini menuntut siswa untuk mereview secara kritis dan mengomunikasikan berbagai manfaat dan kelemahan dari tiap alternatif desain. Proses ini mengajak siswa menganalisis kekuatan dan kelemahan desain mereka (iStudy, 2006). Investigasi dalam tahapan STEM menjadikannya sebagai tempat pelatihan ideal untuk memajukan cara berpikir yang objektif dan kritis pada diri siswa mereka (West, 2012). Adanya tes formatif di tiap pertemuan mendorong proses asimilasi siswa, hal ini juga berpengaruh positif pada keterlibatan dan kepercayaan diri siswa dalam mengikuti tahapan pembelajaran (Evans, dkk, 2014). Kepercayaan diri yang tinggi dalam proses belajar dapat membantu meningkatkan tingkat berpikir kritis siswa (Dehghani, dkk, 2011).

Chen dkk. (2019) menyatakan bahwa proses pembelajaran STEM PjBL menuntut siswa berpikir secara kritis dan analitik sehingga meningkatkan keterampilan berpikir tingkat tinggi siswa. Tseng, dkk (2013) dan Ralph (2016) menyatakan bahwa kombinasi PjBL dengan STEM menghasilkan pembelajaran bermakna dan memberi pengaruh pada sikap siswa dalam pengejaran karir di masa depan. PjBL melatih siswa untuk memahami konsep melalui pembuatan produk, kemudian dalam STEM terjadi 
proses perancangan dan redesign (engineering design process) yang mengajarkan siswa untuk membuat produk terbaik. Penilaian otentik pada proses pembelajaran juga berkontribusi terhadap peningkatan kemampuan berpikir kritis siswa (Pantiwati 2013). Adanya penilaian otentik melengkapi proses pembelajaran STEM PjBL karena penilaian otentik harus dirancang untuk siswa yang belajar dengan menggunakan unsur engineering (Guzzomi, dkk, 2017). Kemampuan berpikir siswa khususnya pada tingkat pemikir kritis banyak dilatih pada proses engineering. Capraro, et al. (2013) dalam penelitiannya mengungkapkan jika engineering pada STEM PjBL memiliki banyak kegunaan terhadap proses pembelajaran. Salah satunya ialah menyediakan struktur yang sistematis dalam melatih siswa untuk memecahkan masalah yang kompleks, proses ini diketahui mampu melatih kemampuan berpikir kritis siswa.

Mutakinati, Anwari, \& Yoshisuke (2018) dalam penelitiannya mengungkapkan bahwa proses pembelajaran dalam STEM PjBL mampu membuat siswa untuk menjadi pemikir rata-rata. Pemikir rata-rata merupakan tahap pengembangan berpikir kritis, pada tahap ini siswa telah memiliki keterampilan berpikir yang cukup untuk membangun cara berpikir logis dan melakukan pertimbangan atas keputusan yang diambil. Hal ini dibuktikan dengan siswa yang masih mengalami miskonsepsi dengan menganggap tekanan di dalam gua lebih kecil dibandingkan di luar gua saat pre-test dan saat postest siswa sudah memiliki pemahaman yang mendalam terkait konsep tekanan hidrostatis, siswa memperhatikan persamaan matematis dalam melakukan identifikasi dan evaluasi hipotesis. Penilaian otentik pada proses pembelajaran juga berkontribusi terhadap peningkatan kemampuan berpikir kritis siswa (Pantiwati, 2013). Adanya penilaian otentik melengkapi proses pembelajaran STEM PjBL karena penilaian otentik harus dirancang untuk siswa yang belajar dengan menggunakan unsur engineering (Guzzomi, et al, 2017).

STEM PjBL disertai penilaian otentik cukup bagus untuk diterapkan oleh guru, karena proses pembelajarannya sesuai dengan tuntutan kurikulum 2013. Proses yang ada pada model ini mengajarkan siswa untuk berpartisipasi aktif dan mandiri dalam membuat solusi melalui perancangan proyek untuk memecahkan masalah yang erat kaitannya dengan kehidupan manusia. Adanya penilaian otentik juga menciptakan motivasi belajar yang baik pada siswa, karena akan ada apresiasi atas setiap tahap yang dilakukan siswa. Meskipun kemampuan berpikir kritis siswa meningkat secara umum, tidak dapat dipungkiri bahwa hal ini tidak terjadi pada semua siswa. Terdapat beberapa siswa yang memiliki nilai pre-test dan postest yang sama bahkan memiliki nilai postest yang lebih rendah dari pre-test. Ini merupakan akibat dari proses pembelajaran yang terlaksana dengan kurang maksimal dan soal yang tidak memberikan instruksi secara jelas. Anggota kelompok terlalu besar membuat kemampuan ini tidak dapat dilatihkan secara merata kepada seluruh siswa. Untuk guru atau para peneliti yang berminat melakukan penelitian serupa diharapkan untuk mengoordinir siswa menjadi kelompok dengan anggota yang lebih kecil, maksimal anggota tiap kelompok adalah empat orang. Dengan demikian, proses pembelajaran STEM PjBL disertai penilaian otentik akan terlaksana dengan lebih optimal.

\section{SIMPULAN}

Secara umum, kemampuan berpikir kritis siswa lebih baik setelah kegiatan belajar mengajar menggunakan STEM PjBL disertai penilaian otentik. Kemampuan berpikir kritis siswa meningkatkan pada indikator identifikasi hipotesis, induksi, deduksi, penjelasan dan evaluasi.

\section{DAFTAR RUJUKAN}

Chen, C. S., \& Jing-Wen Lin. (2019). A Practical Action Research Study of the Impact of Maker-Centered STEM-PjBL on a Rural Middle School in Taiwan. International Journal of Science and Mathematics Education, 17(S1), 85-108.

Dehghani, Marzieh, Hossein Jafari sani, Hamideh Pakmehr, dan Asma Malekzadeh. (2011). Relationship between Students' Critical Thinking and Self-Efficacy Beliefs in Ferdowsi University of Mashhad, Iran. Procedia - Social and Behavioral Sciences, 15, 2952-55.

Marisda, D. H. (2019). The Effect of Task-Based Collaborative Learning on Students' Mathematical Physics Learning Outcomes at Universitas Muhammadiyah Makassar. Jurnal Pendidikan Fisika, 7(2), 140-50.

Evans, D. J. R., Paul Zeun., \& Robert A. Stanier. (2014). Motivating Student Learning Using a Formative Assessment Journey. Journal of Anatomy, 224(3), 296-303.

Fayakun, M., \& Joko, P. (2015). Efektivitas Pembelajaran Fisika menggunakan Model Kontekstual dengan Metode Predict, Observe, Explain terhadap Kemampuan Berpikir Tingkat Tinggi. Jurnal Pendidikan Fisika Indonesia, 11(1), 49-58.

Goszewski, M., Moyer, A., Bazan, Z., \& D. J. Wagner. (2013). Exploring Student Difficulties with Pressure in a Fluid. AIP Conference Proceedings, 1513, 154-57.

Guzzomi, A. L., Sally A. Male., \& Karol Miller. (2017). Students' Responses to Authentic Assessment Designed to Develop Commitment to Performing at Their Best. European Journal of Engineering Education, 42(3), 219-240.

Hake, R. R. (1998). Interactive-Engagement versus Traditional Methods. American Journal of Physics, 66, 64-74. http://www.bedu.com/Publications/ajpv3i.pdf.

Insyasiska, D., Zubaidah, S., \& Susilo, H. (2015). Pengaruh Project Based Learning terhadap Motivasi Belajar, Kreativitas, Kemampuan Berpikir Kritis, dan Kemampuan Kognitif Siswa pada Pembelajaran Biologi. Jurnal Pendidikan Biologi, 7(1), 9-21.

Loverude, M. E., P. R. L. Heron., \& C. H. Kautz. (2010). Identifying and Addressing Student Difficulties with Hydrostatic Pressure. American Journal of Physics, 78(1), 75-85. 
Mihardi, S., Harahap, M. B., \& Sani, R. A. (2013). The Effect of Project Based Learning Model with KWL Worksheet on Student Creative Thinking Process in Physics Problems. Journal of Education and Practice, 4(25), 188-200.

Mohamadi, Z. (2018). Comparative Effect of Project-Based Learning and Electronic Project-Based Learning on the Development and Sustained Development of English Idiom Knowledge. Journal of Computing in Higher Education, 30 (2), 363-85.

Mutakinati, L., Anwari, I., \& Yoshisuke, K. (2018). Analysis of Students' Critical Thinking Skill of Middle School through Stem Education Project-Based Learning. Jurnal Pendidikan IPA Indonesia, 7(1), 54-65.

Nuryanti, L., Zubaidah, S., \& Diantoro, M. (2018). Analisis Kemampuan Berpikir Kritis Siswa SMP. Jurnal Pendidikan: Teori, Penelitian, dan Pengembangan, 3(2), 155-158.

Pantiwati, Y. (2013). Authentic Assessment for Improving Cognitive Skill, Critical-Creative Thinking and Meta-Cognitive Awareness. Journal of Education and Practice, 4(14), 1-10.

Priyadi, R., Mustajab, A., Tatsar, M. Z., \& Kusairi, S. (2018). Analisis Kemampuan Berpikir Kritis Siswa SMA Kelas X MIPA Dalam Pembelajaran Fisika. JPFT (Jurnal Pendidikan Fisika Tadulako Online), 6(1), 53.

Puspita, I., Kaniawati, I., \& Suwarma, I. R. (2017). Analysis of Critical Thinking Skills on the Topic of Static Fluid. Journal of Physics: Conference Series, 895(1).

Ralph, R. A. (2016). Post Secondary Project-Based Learning in Science, Technology, Engineering and Mathematics. Journal of Technology and Science Education, 6(1), 26-35.

Tiruneh, D. T., Cock, M. D., Weldeslassie, A. G. \& Janssen, R. (2017). Measuring Critical Thinking in Physics: Development and Validation of a Critical Thinking Test in Electricity and Magnetism. International Journal of Science and Mathematics Education, 15(4), 663-682.

Tseng, K. H., Chang, C. C., Lou, S. J., \& Chen, W. P. (2013). Attitudes towards Science, Technology, Engineering and Mathematics (STEM) in a Project-Based Learning (PjBL) Environment. International Journal of Technology and Design Education, 23(1), 87-102.

Wijaya, C. P., Koeshandayanto, S., \& Muhardjito. (2016). The Diagnosis of Senior High School Class X MIA B Students Misconceptions about Hydrostatic Pressure Concept Using Three-Tier. Jurnal Pendidikan IPA Indonesia, 5(1), 14-21.

Yadaeni, A., Kusairi, S., \& Parno. (2018). Penguasaan Konsep dan Keterampilan Proses Sains Siswa Kelas XII pada Materi Fluida Statis. Jurnal Pendidikan: Teori, Penelitian, dan Pengembangan, 3(3), 357-364.

Yolanda, V., Fakhruddin., \& Yennita. (2017). Analysis of Student Misconceptions in Physics Learning of Static Fluid Materials Using Certain of Response Index (CRI) Method in SMAN 7 Pekanbaru. 